\title{
Determination of Metal Hazard in the Processed E-Waste Types, Floor Dust and Pulverized Epoxy Powder Generated at an E-Waste Handling Site in India
}

\author{
P. Wagdevi ${ }^{1}$, R. Jayakumar ${ }^{2 *}$, P. Rajaguru ${ }^{3}$, S. Muralidharan ${ }^{4}$, \\ A. Kaja Maideen ${ }^{5}$ and Prakasham Karthikeyan ${ }^{6}$ \\ ${ }^{1 \& 2}$ Gandhi Institute of Technology and Management, Bengaluru Campus, Karnataka, India \\ ${ }^{3}$ Bharathidasan Institute of Technology, Anna University, Tiruchirappalli, Tamil Nadu, India \\ ${ }^{4,5 \& 6}$ Salim Ali Centre for Ornithology and Natural History (SACON), Anaikatti, Coimbatore, Tamil Nadu, India \\ *Corresponding Author \\ E-Mail: rjkumar8@yahoo.com,wagdevipatnaik@gmail.com
}

\begin{abstract}
At the e-waste handling site, the obsolete electronic items are dismantled and it releases dust laden with fine metallic fragments, called as floor dust. Further, the broken cables are denuded from its plastic insulation and shredded to fine grained pulverized epoxy powder. These two-processed ewastes appear to contain metal residues. Hence, the aim is to examine the metal composition and identify the hazard, if any. Pulverized epoxy powder measured high values of $\mathrm{Cd}$ (7.43 $\pm 0.48 \mu \mathrm{g} / \mathrm{g}), \mathrm{Pb}(338.85 \pm 0.13 \mu \mathrm{g} / \mathrm{g}), \mathrm{Ni}(534.62 \pm 53.68 \mu \mathrm{g} / \mathrm{g})$, $\mathrm{Li} \quad(30.12 \pm 0.02 \mu \mathrm{g} / \mathrm{g}), \quad \mathrm{K} \quad(508109.90 \pm 31605.89 \mu \mathrm{g} / \mathrm{g}), \quad \mathrm{Ca}$ $(817395.40 \pm 2.52 \mu \mathrm{g} / \mathrm{g})$ and $\mathrm{Na}(3528.00 \pm 539.07 \mu \mathrm{g} / \mathrm{g})$ while floor dust had high levels of $\mathrm{Cr}(39.61 \pm 5.78 \mu \mathrm{g} / \mathrm{g}), \mathrm{Cu}$

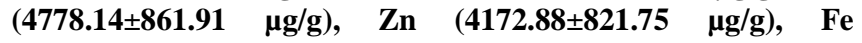
$(11164.90 \pm 1111.61 \mu \mathrm{g} / \mathrm{g})$ and Se $(1613.00 \pm 259.04 \mu \mathrm{g} / \mathrm{g})$ with significant differences $(\mathbf{p}<0.05)$. The worn out electronic oddments attributes to high levels of metals. Principal component analysis could extract two components accounting for $78 \%$ variance in total. Although the values are less in comparison with the statutory limits, the processed e-wastes still pose a risk of metal toxicity due to their high volume. The composition of metals in the processed e-wastes presents us a new challenge to handle them.
\end{abstract}

Keywords: E-Waste Handling, Floor Dust, Pulverized Epoxy Powder, Metals

\section{INTRODUCTION}

E-waste refers to the 'Waste Electrical and Electronic Equipment' (WEEE). Owing to progressive technological changes in the global electronic sector, many of the existing electronic devices has become no longer in use. This has resulted in steep production of e-wastes. Globally, 20 million tonnes of e-waste are added annually and it is forecasted that the quantity will escalate up to $49.8 \mathrm{Mt}$ in $2018(1,2)$. Among the nations, China ranks first in generation of e-waste at a rate of 6 million tonnes per year (3). Currently, in India about 4.1 million tonnes of e-wastes are generated and it is expected to reach 8 million tonnes by 2025 (4). Although a disproportionate generation of ewaste is observed among the various states of India, about 9118.74 tonnes are generated every year at Bengaluru, Karnataka and handled at various e-waste handling sites (rajyasabha.nic.in). The present e-waste handling methods include the collection, segregation, dismantling, recovery and disposal. Most of these methods are manual, crude and primitive due to the expensive high-tech recovery process (5). It is understood that e-wastes contain 40-50 times more precious metals like gold than natural ores (6). Hence, recovery of precious metals from e-waste is practiced informally through open burning and strong acid digestion in backyards by recyclers. This results in the release of toxic contaminants such as metals, polychlorinated biphenyls (PCBs), Dioxins and Furans which are injurious to the surrounding biota. (7).

In India, the Central Pollution Control Board has framed guidelines to handle e-waste and has licensed 138 formal recycling/handling units. The present study was carried at one such licensed e-waste handling unit in Bengaluru, Karnataka. At this site, it was observed that obsolete electronic items received from all the local waste collectors, IT corporate companies and other industries were dumped on the storage yard. They are initially segregated into metal and non-metallic components which results in dust laden with fine metallic fragments, exudes from the worn-out batteries and glass bits. Thus, huge quantities of floor dust are produced from e-waste segregation. The electrical equipment is wrenched from its fixtures and broken into smaller pieces. The printed circuit boards are chopped into specific dimensions and exported to countries like Germany for precious metal recovery. The bulbs and tubes are crushed in an automated crusher and recycled for further use. The worn-out wires are stripped to separate the copper from plastic insulation and pulverized to powder which may contain metal residues. Hazardous batteries were safely shifted to the nearby transport, storage and disposal facility established by the pollution control board of the state government, Karnataka, India. Thus, two processed ewastes such as floor dust and pulverized epoxy powder are generated out of e-waste handling which may contain metal residues.

The objective of this study to identify the metal hazard in two processed forms of e-wastes, namely floor dust and pulverized epoxy powder generated through dismantling 
and shredding of the worn-out wires for metal recovery, respectively. Hence, we attempted to examine the metal composition present in the two forms of e-waste. Metals such as $\mathrm{Cd}, \mathrm{Pb}, \mathrm{Ni}, \mathrm{Cr}, \mathrm{Cu}, \mathrm{Zn}, \mathrm{Fe}, \mathrm{Se}, \mathrm{Li}, \mathrm{K}, \mathrm{Ca}$ and $\mathrm{Na}$ were quantified and their levels were compared with the statutory limits set by India and California State, USA to classify the waste as hazardous. A Principal Component Analysis (PCA) was conducted to extract the major components of metals in e-wastes. As the processed ewastes is expected to contain metals, the feasibility of using vermin remediation to recover the metals is also discussed.

\section{A. Statement of Novelty}

This study characterized metals in the processed e-wastes such as floor dust and pulverized epoxy powder which are generated during e-waste handling. They contain high levels of metals. The metal levels are far lesser than the statutory limits. Nevertheless, the high volume of processed e-wastes still poses a high risk of metal toxicity. This study has identified the hazard composition of metals and presents a new challenge to handle them. Further, this study gives a scope to identify the possibility of vermin remediation to recover metals.

\section{MATERIALS AND METHODS}

\section{A. Study Site}

Dobaspet Industrial Area, Bengaluru Rural District, Karnataka $\left(12.991^{\circ} \mathrm{N} ; 77.7094^{\circ} \mathrm{E}\right)$ is one of the major industrial area (1225 acres) established by Karnataka Industrial Area Development Board (KIAB), Govt. of Karnataka (Fig 1). There are 38 e-waste recycling units approved by the State Pollution Control Board at Karnataka and a major e-waste handling unit is located at this industrial area spread on 1.5 acres of land. The current capacity of the unit is to handle 6 tonnes/day. It has an integrated production line for recycling the worn-out cables and waste wires handling 3 tons/hr along with wire strippers.

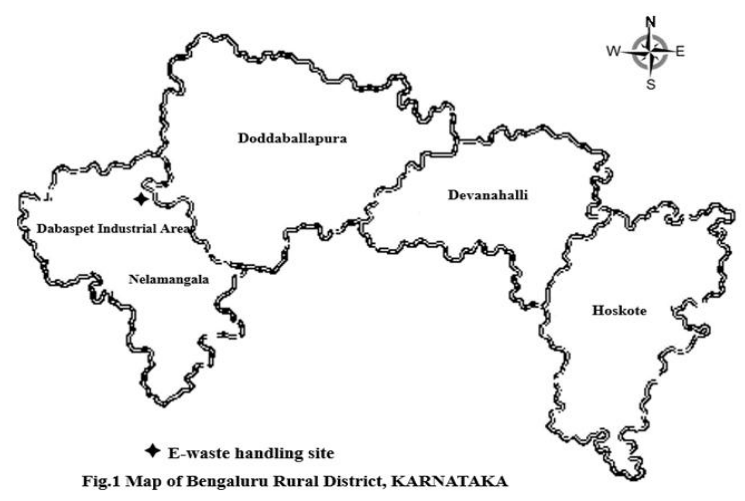

Fig.1 Map of Benagluru Rural District, Karnataka

\section{B. Sample Collection}

A total of 20 samples of floor dust and pulverized epoxy powder were collected from the e-waste handling unit. The floor dust was swept manually with a plastic sterile brush from the dismantling area and the pulverized epoxy powder generated from the cable shredding machine were collected, stored in pre-cleaned polythene bag and transported to the laboratory. At laboratory, they are grounded and sieved to obtain a fine powder and subjected to acid digestion.

\section{Sample Digestion and Analysis}

The procedure for digestion of samples was followed as per Jayakumar and Muralidharan (2015) with slight modifications. Briefly, about $1.5 \mathrm{~g}$ of the sample was weighed, digested using Microwave Digestion System (Milestone, MLS 1200) in $10 \mathrm{~mL} \mathrm{HNO}_{3}$ (69\% GR-Merck) for $10 \mathrm{~min}, 1 \mathrm{~mL} \mathrm{HClO}_{4}(70 \%$ GR-Merck) for $5 \mathrm{~min}$ and 10 $\mathrm{mL} \mathrm{H}_{2} \mathrm{O}_{2}$ (30\% GR-Merck) for $10 \mathrm{~min}$ at $250 \mathrm{~W}$ magnetron power settings and analysed for metals such as $\mathrm{Cd}, \mathrm{Pb}, \mathrm{Ni}$, $\mathrm{Cr}, \mathrm{Cu}, \mathrm{Zn}, \mathrm{Fe}, \mathrm{Se}, \mathrm{Li}, \mathrm{K}, \mathrm{Ca}$ and $\mathrm{Na}$ using a double beam Atomic Absorption Spectrometer (Perkin Elmer, Model AA800). Standards for metals manufactured by Merck, India (99.9\% pure) were used to calibrate the instrument. To validate calibration during measurements, for every ten samples, blank and calibration standards were read thrice and relative standard deviation was computed. While the detection limit for $\mathrm{Cu}, \mathrm{Cr}, \mathrm{Fe}, \mathrm{K}, \mathrm{Li}, \mathrm{Ca}, \mathrm{Na}, \mathrm{Se}$ and $\mathrm{Ni}$ and was $0.002 \mathrm{ppm}$, the same for $\mathrm{Cd}, \mathrm{Pb}$ and $\mathrm{Zn}$ was $0.001,0.03$ and $0.02 \mathrm{ppm}$ respectively. The quantification limits of metals were three times the detection limit. Recovery rates for $\mathrm{Cu}, \mathrm{Cd}, \mathrm{Pb}, \mathrm{Zn}, \mathrm{Cr}$ and $\mathrm{Ni}$ were 86, 88, 85, 90, 87 and $89 \%$, respectively. $\mathrm{Na}, \mathrm{Ca}, \mathrm{Li}, \mathrm{Se}, \mathrm{Fe}$ and $\mathrm{K}$ had recovery rates in the range of $90-95 \%$. The results were not corrected for percent recovery and expressed in $\mu \mathrm{g} / \mathrm{g}$ (mean $\pm \mathrm{S}$.E).

\section{Statistical Analysis}

The data was subjected to statistical analysis using SPSS software Ver.17. Descriptive statistics showed the distribution and the normality was ensured with ShapiroWilk test. An Independent sample t-test was performed to identify the mean differences of metals in floor dust and pulverized epoxy powder. Under Levene's test for equality of variance, we considered the 'equal variances not assumed' to interpret the significance in variation at $\mathrm{p}<0.05$. Eta squared was used to calculate the effect size for the Independent sample t-test. Principal Component analysis was performed only on select 7 metals such as $\mathrm{Pb}, \mathrm{Cr}, \mathrm{Cu}$, $\mathrm{Zn}, \mathrm{Ca}, \mathrm{K}$ and $\mathrm{Fe}$ as their individual Kaiser-Mayer-Olkin values measured were greater than 0.5 . The factor analysis was conducted with varimax orthogonal rotation. The components were extracted for Eigen values $<1$.

\section{RESULTS AND DISCUSSION}

\section{A. Variation in Metal Contamination between the E-Waste Samples}

Altogether 20 samples of floor dust and pulverized epoxy powder analysed for metals showed significant variation. Among the metals, $\mathrm{Ca}$ and $\mathrm{K}$ were found to be highest in 
floor dust and pulverized epoxy powder (Fig.2 A). The average $\mathrm{Ca}(817395.40 \pm 2.52 \mu \mathrm{g} / \mathrm{g})$ levels in pulverized epoxy powder was 28 times higher than the floor dust $(\mathrm{Ca}=$ $29408.50 \pm 2775.50 \mu \mathrm{g} / \mathrm{g})$. Further, K (508109.90 \pm 31605.89 $\mu \mathrm{g} / \mathrm{g}$ ) values recorded in pulverized epoxy powder was twice higher than the levels reported in floor dust $(\mathrm{K}=$ $248213.90 \pm 5853.64 \mu \mathrm{g} / \mathrm{g})$. However, no significant variation $(\mathrm{p}>0.05)$ was observed.

Metals such as $\mathrm{Fe}, \mathrm{Cu}, \mathrm{Zn}$ were found to be significantly higher in floor dust $(\mathrm{Fe}=11164.90 \pm 1111.61 \mu \mathrm{g} / \mathrm{g} ; \mathrm{Cu}=$ 4778.14 $\pm 861.91 \mu \mathrm{g} / \mathrm{g} ; \mathrm{Zn}=4172.88 \pm 821.75 \mu \mathrm{g} / \mathrm{g}$ ) (Fig.2 B) than pulverized epoxy powder $(\mathrm{Fe}=4219.30 \pm 374.53 \mu \mathrm{g} / \mathrm{g}$; $\mathrm{Cu}=1109.12 \pm 236.70 \mu \mathrm{g} / \mathrm{g} ; \mathrm{Zn}=395.70 \pm 62.45 \mu \mathrm{g} / \mathrm{g})$. The magnitude of differences in the means for $\mathrm{Fe}(\mathrm{t}=-5.92$; MD $=-6945.60 ; 95 \% \mathrm{CI}=-9536.88$ to -4364.32$), \mathrm{Cu}(\mathrm{t}=-$ 4.105; $\mathrm{MD}=-3669.02 ; 95 \% \mathrm{CI}=5651.49$ to -1686.55$), \mathrm{Zn}$ $(\mathrm{t}=-4.583 ; \mathrm{MD}=-3777.19 ; 95 \% \mathrm{CI}=-5638.23$ to -1916.14$)$ was very large (Eta square>0.6). The levels of $\mathrm{Na}$ $(3528.00 \pm 539.07 \mu \mathrm{g} / \mathrm{g})$ and $\mathrm{Se}(1960.80 \pm 9.03 \mu \mathrm{g} / \mathrm{g})$ was found to be higher in pulverized epoxy powder than floor dust $(\mathrm{Na}=3066.50 \pm 325.14 \mu \mathrm{g} / \mathrm{g} ; \mathrm{Se}=1613.00 \pm 259.04$ $\mu \mathrm{g} / \mathrm{g})$. However, no significant differences in their levels could be found.

Non-essential toxic metals such as $\mathrm{Pb}, \mathrm{Ni}, \mathrm{Cr}, \mathrm{Cd}$ and $\mathrm{Li}$ were found to be appreciably detected in both E-waste samples (Fig.2 C\&D). However significant variation could be noticed only for $\mathrm{Pb}, \mathrm{Ni}$ and $\mathrm{Cr} \quad(\mathrm{p}<0.05)$. $\mathrm{Pb}$ $(338.85 \pm 0.13 \mu \mathrm{g} / \mathrm{g})$ and $\mathrm{Ni}(534.62 \pm 53.68 \mu \mathrm{g} / \mathrm{g})$ levels were significantly high in pulverized epoxy powder and their mean differences $(\mathrm{Pb}-\mathrm{t}=100.32 ; \mathrm{df}=10.42 ; \mathrm{MD}=46.49$; $95 \% \mathrm{CI}=45.46$ to $47.52 ; \mathrm{Ni}-\mathrm{t}=3.10$; $\mathrm{df}=12.35 ; \mathrm{MD}=$ $181.50 ; 95 \% \mathrm{CI}=54.15$ to 308.85$)$ were high (Eta square = >0.6). $\mathrm{Cd}(7.43 \pm 0.48 \mu \mathrm{g} / \mathrm{g})$ and $\mathrm{Li}(30.12 \pm 0.02 \mu \mathrm{g} / \mathrm{g})$ were also found to be higher in pulverized epoxy powder. However, no significant variation $(p>0.05)$ could be observed. $\mathrm{Cr}$ was found to be higher in floor dust $(39.61 \pm 5.78 \mu \mathrm{g} / \mathrm{g})$ than pulverized epoxy powder $(6.30 \pm 1.09 \mu \mathrm{g} / \mathrm{g})$ and their mean differences were also significant $(\mathrm{t}=-5.66 ; \mathrm{df}=9.64 ; \mathrm{MD}=-33.31 ; 95 \% \mathrm{CI}=-$ 46.48 to -20.14$)$.

Thus, pulverized epoxy powder measured high values of $\mathrm{Cd}, \mathrm{Pb}, \mathrm{Ni}, \mathrm{Li}, \mathrm{K}, \mathrm{Ca}$ and $\mathrm{Na}$ while floor dust had high levels of $\mathrm{Cr}, \mathrm{Cu}, \mathrm{Zn}, \mathrm{Fe}$ and $\mathrm{Se}$. Pulverized epoxy powder is a type of processed e-waste produced during the removal of copper wire from its plastic insulation to recover copper. The worn-out copper cables contain plastic wrappings, mutilated soldered edges, wall paint spillages and corroded green colour exudes. Further, the printed circuit boards and capacitors are also shredded to remove the metal. In the event of separating the metal from the non-metallic parts, the copper wires from worn-out cables and PCBs are stripped from the plastic insulation, shred and pulverized. This handling procedure might attribute to high levels of metals in the pulverized epoxy powder which plausibly contains a mixture of metals.
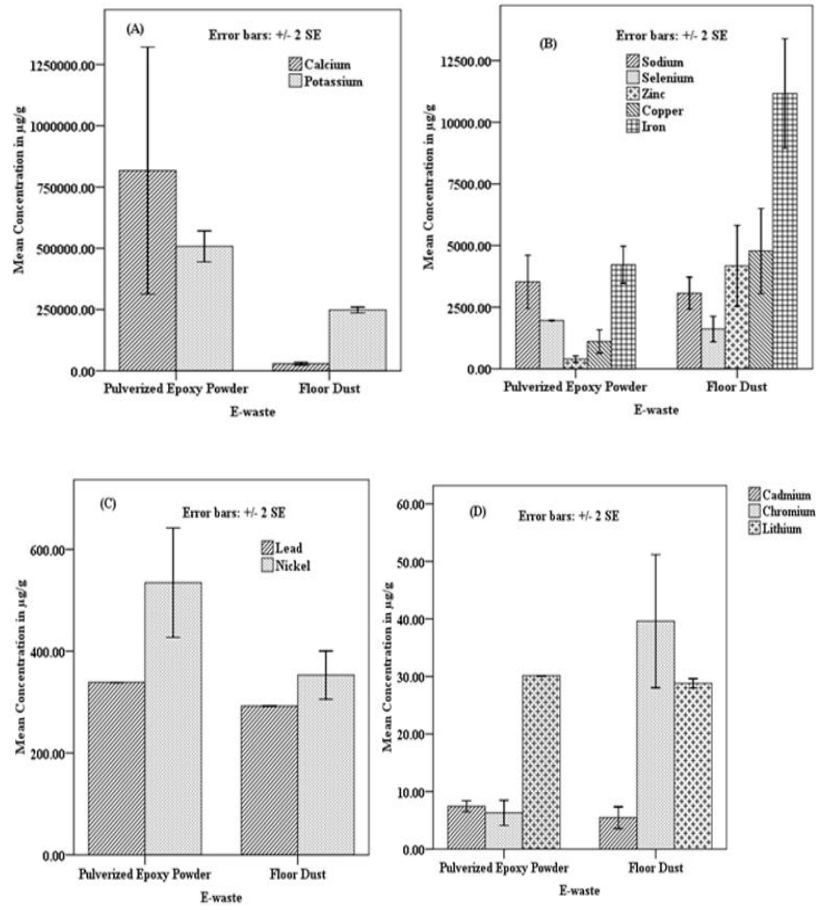

Fig. 2 Variation in metal levels between the processed e-wastes

Floor dust is a type of processed E-waste generated, when obsolete electronic items undergo segregation and dismantling at handling site. It contains the external dust adhered to the electronic items during transportation or the dust already present during disposal, transudes from the worn-out batteries, scrap paint remnants, broken glass coverings, metal screws and nuts. It is understood, the floor dust is a mixture of these electronic oddments. Hence, the high level of metals in the floor dust is attributed to the mixture of the electronic oddments. This E-waste is generally swept and disposed to the local Karnataka State Transport, Storage and Disposal site.

The significant high levels of $\mathrm{Pb}$ and $\mathrm{Ni}$ in the pulverized epoxy powder may be due to blemished soldering, mutilated $\mathrm{PCBs}$ and $\mathrm{Ni}$ sheds from the paint coatings of the plastic laces of the metal wires which are expelled during the process of shredding the PCBs, stripping and pulverizing of wires. PCBs are the major components of E-waste (about $85 \%$ ) and they contain both non-metallic (plastics, epoxy, resins, and glasses) and metal (copper, iron, lead, and nickel) components (8). They are mainly chipped out from mobile phones, computers, television sets and other domestic household and industrial appliances to recover metals.

The present reported metal concentrations of $\mathrm{Pb}, \mathrm{Cd}, \mathrm{Ni}, \mathrm{Cr}$, $\mathrm{Se}, \mathrm{Cu}$, and $\mathrm{Zn}$ in floor dust and pulverized epoxy powder were far lesser than the values reported in studies conducted on printed circuit boards of mobile phones and other electrical waste components. In a study conducted on wornout printed circuit boards of different discarded mobile phones at Nigeria to determine metals showed very high levels of $\mathrm{Cu}(250000 \pm 92300 \mathrm{mg} / \mathrm{kg}), \mathrm{Pb}(20100 \pm 8400$ 
$\mathrm{mg} / \mathrm{kg})$ and $\mathrm{Cd}(2100 \pm 3300 \mathrm{mg} / \mathrm{kg})$. Further, there are studies which reported mean $\mathrm{Cu}$ concentration of 203000 $\mathrm{mg} / \mathrm{kg}$ (range 186000-224000 mg/kg), $\mathrm{Pb}$ (mean- 10140 $\mathrm{mg} / \mathrm{kg}$; range $8220-11600 \mathrm{~g} / \mathrm{kg}$ ), Cd (mean - $2.93 \mathrm{mg} / \mathrm{kg}$; range $2.67-3.40 \mathrm{mg} / \mathrm{kg}$ ), total $\mathrm{Cr}$ (mean $-958 \mathrm{mg} / \mathrm{kg}$; range $-958 \mathrm{~g} / \mathrm{kg}$; range $-253-2330 \mathrm{mg} / \mathrm{kg}$ ), $\mathrm{Ni}$ (mean $9247 \mathrm{mg} / \mathrm{kg}$; range- $6340-11200 \mathrm{mg} / \mathrm{kg}$ ), Se (mean - 5.9 $\mathrm{mg} / \mathrm{kg}$; range $-4.81-6.90 \mathrm{mg} / \mathrm{kg}$ ) and $\mathrm{Zn}$ (mean - 11007 $\mathrm{mg} / \mathrm{Kg}$; range $-8820-12880 \mathrm{mg} / \mathrm{kg}$ ) in mobile phones (9) characterized and quantified metals such as $\mathrm{Pb}$ $(600000 \pm 200 \mathrm{mg} / \mathrm{kg}), \mathrm{Ni}(50.0 \pm 34.0 \mathrm{mg} / \mathrm{kg}), \mathrm{Cr}(65.4 \pm 40$ $\mathrm{mg} / \mathrm{kg}), \mathrm{Cu}(6.81 \pm 5.0 \mathrm{mg} / \mathrm{kg}), \mathrm{Zn}(5.98 \pm 3.0 \mathrm{mg} / \mathrm{kg})$ and $\mathrm{Fe}$ $(40.2 \pm 35 \mathrm{mg} / \mathrm{kg})$ in battery electrodes of waste rechargeable electric lamps. A study conducted on the electrical components of mosquito bat (10) showed very high levels of $\mathrm{Pb}$ which range between 3574 and $7575 \mathrm{mg} / \mathrm{kg}$. However, the values of $\mathrm{Fe}$ and $\mathrm{Se}$ in the present study are observed to be higher. Further $\mathrm{Na}, \mathrm{Ca}$ and $\mathrm{K}$ are essential metals and their levels could not be compared as there exists no data in e-waste.

The regulatory toxicity threshold limit concentration (TTLC) values set by the State of California, USA, in classifying solid waste as hazardous for metals such as $\mathrm{Cd}$, $\mathrm{Pb}, \mathrm{Ni}, \mathrm{Cr}$ (total), $\mathrm{Cu}, \mathrm{Zn}$ and $\mathrm{Se}$ are 100, 1000, 2000, 2500, 2500,5000 and 100 respectively. In India, the E-waste handling and management rule 2011 has set a maximum permitted limit for $\mathrm{Pb}$ and $\mathrm{Cd}$ as 1000 and $100 \mathrm{ppm}$, respectively (The Gazette of India, 2011). The reported values in floor dust and pulverized epoxy powder are within the statutory limits. However, the risk of metal toxicity cannot be discounted owing to their huge volume.

A study on metals on the indoor dust of e-waste workshop (11) reported high values of $\mathrm{Pb}(9630 \mathrm{mg} / \mathrm{kg}), \mathrm{Cd}(10.8$ $\mathrm{mg} / \mathrm{kg}), \mathrm{Ni}(360 \mathrm{mg} / \mathrm{kg}), \mathrm{Cu}(5150 \mathrm{mg} / \mathrm{kg})$ and $\mathrm{Zn}(1360$ $\mathrm{mg} / \mathrm{kg}$ ). The present recorded values for metals such as $\mathrm{Cd}$, $\mathrm{Cu}, \mathrm{Ni}$ and $\mathrm{Zn}$ in floor dust are comparable. Although their concentrations are minimum 1.5 times lower than the values recorded in the indoor dust of e-waste workshop, upon chronic exposure it can cause serious health problems to the e-waste handlers.

\section{B. Principal Component Analysis of Metals in E-Waste Samples}

PCA conducted on select seven metals such as $\mathrm{Pb}, \mathrm{Cr}, \mathrm{Cu}$, $\mathrm{Zn}, \mathrm{Ca}, \mathrm{K}$ and $\mathrm{Fe}$ with orthogonal varimax rotation had good sampling adequacy. It was verified through KaiserMeyer-Olkin measure $(\mathrm{KMO}=0.817)$. Further, the KMO values for the metals examined were $>0.5$. Bartlett's test of Sphericity $\mathrm{X}^{2}=101.72, \mathrm{p}<0.05$ showed that correlations between the metals was appreciable. With Eignen values $>1$, two components could be extracted. It explained the $79 \%$ variance in combination of factor 1 (48\% variance) and factor 2 (10\% variance) with loadings of $\mathrm{Pb}, \mathrm{Cr}, \mathrm{K}, \mathrm{Fe}, \mathrm{Cu}$, $\mathrm{Zn}$ and $\mathrm{Ca}$, respectively.

The combination of metals such as $\mathrm{Pb}, \mathrm{Cr}, \mathrm{K}, \mathrm{Fe}, \mathrm{Cu}$ and $\mathrm{Zn}$ in component 1 indicated that these metals are used commonly in manufacture of any electrical components. Thus, their occurrence in the studied E-wastes could be accounted. The component 2 exclusively indicated $\mathrm{Ca}$ which is a fifth abundant alkaline earth metal commonly employed an alloying agent for many metals in electrical components. The component 1 represents a combination of alkaline and heavy metals while the component 2 shows only the alkaline earth metal.

This study has identified significant variation in levels of metals between two types of processed e-wastes. Although both the wastes had high levels of metals, pulverized epoxy powder had high levels of toxic metals such as $\mathrm{Cd}, \mathrm{Pb}$ and $\mathrm{Ni}$ than floor dust. As these wastes are generated out of handling and processing of e-waste, they do have fair chances of metal contamination. In comparison with the values reported in literature and statutory limits, the levels are far lesser. However, the risk of metal toxicity in disposing these e-wastes cannot be ignored owing to their high volume being continuously generated. It is needless to mention that E-wastes require proper treatment mechanisms before they are disposed. In India, still primitive methods of incineration and land fill techniques are practiced which has resulted in the contamination of soil, water and plant in Mandoli Industrial area, Delhi (12).

\section{CONCLUSION}

The present e-wastes generated appear to contain good levels of valuable metals such as $\mathrm{Cu}, \mathrm{Fe}$ and $\mathrm{Zn}$ which may be recovered through the available hydro metallurgical, pyro metallurgical and bio leaching process (13). Further, vermin remediation may also be attempted to recover the metals. Earthworms are proven to be potent indicators of soil contamination owing to their sedentary, continuous interaction with soil, ability to bioaccumulate and tolerate the stress produced by the contaminants elevate their role in bioremediation (vermi remediation) of contaminated soil (especially with heavy metals) (14 15). Further, any adverse effect of these e-wastes on earthworm in the form of oxidative stress and genotoxicity could also be mapped. Thus, this study has characterized the metal contents in the wastes generated during the handling and processing of $\mathrm{E}$ waste and now gives us a challenge to take appropriate actions to reduce the wastes, recover the valuable metals thereby practicing sound environmental waste management.

\section{ACKNOWLEDGEMENT}

The present research results are a part of the major research project sanctioned by UGC, Govt. of India, New Delhi (Project No.MRP-MAJOR-ENVI-2013-21394). We thank the funding agency for its financial assistance. The authors are thankful to Dr. S. Muralidharan, Principal Scientist and Dr.K. Sankar, Director, SACON for providing instrumental facility. Further, we also express our sincere gratitude to Gandhi Institute of Technology and Management authorities for their kind support. 


\section{REFERENCES}

[1] C. P. Balde, V. Forti, V. Gray, R. Kuehr and P. Stegmann, "The Global E-waste Monitor - 2017",United Nations University (UNU), International Telecommunication Union (ITU) \& International Solid Waste Association(ISWA), Bonn/Geneva/Vienna..

[2] A. K. Awasthi, X. Zeng and L. Li, "Relationship between e-waste recycling and human health risk in India: a critical review", Environ Sci Pollut Res, Vol. 23, No. 12, pp. 11509-32, 2016.

[3] A. Chen, K. N. Dietrich and S. Ho, "Developmental Neuro toxicants in E-Waste: An Emerging Health Concern", Environ Health Perspect, Vol. 119, pp.431-438, 2011

[4] M. Dwivedy and R.K. Mittal, "An investigation into e-waste flows in India", Journal of Cleaner Production, Vol. 37, pp. 229-242, 2012.

[5] J. Zheng, L. Xj, J. G. Yuan, L. Y. He, Y.H. Zhou, Y. Luo, S.J. Chen, B.X. Mai and Z.Y. Yang, "Heavy metals in hair of residents in an ewaste recycling area, South China: Contents and assessment of bodily state", Arch. Environ. Contam. Toxicol, Vol. 61, pp. 696-703, 2011.

[6] J. K. Pradhan and S. Kumar, "Informal e-waste recycling: environmental risk assessment of heavy metal contamination in Mandoli industrial area, Delhi", India Environ Sci Pollut Res, Vol. 21, pp. 7913-7928, 2014.

[7] A. K. Awasthi, X. Zeng and J. Li, "Relationship between e-waste recycling and human health risk in India: a critical review", Environ Sci Pollut Res, Vol. 23, No. 12, pp.11509-32, 2016.

[8] K. L. Njoku, M. O. Akinola, and C.C. Anigbogu, "Vermiremediation of Soils Contaminated with Petroleum Products using Eisenia fetida", Journal of Applied Science and Environmental Management, Vol. 20, No. 3, pp. 771-779, 2016.
[9] M. B. Ogundiran, T. G. Buluku, J. O. Babayemi and O. Osibanjo, "Waste rechargeable electric lamps: characterisation and recovery of lead from their lead-acid batteries", J Mater Cycles Waste Management, Vol. 19, pp. 163-171, 2017

[10] B. Divya, S. Harish, K. Ramaswamy, M. Kishorebabu, N. Raju, R. Govindaiah, U. Rambabu and N. R. Munirathnam, "Estimation of Cd, $\mathrm{Pb}$ and flame retardants in electric mosquito bat using EDXRF, ICPOES, AAS and GC-MS", Int. J. Environ. Sci. Technol, Vol. 14 No.12, pp. 2603-2612, 2017.

[11] F. Xu, Y. Liu, J. Wang, G. Zhang, W. Zhang, L. Liu, J. Wang, B. Pan and K. Lin, "Characterization of heavy metals and brominated flame retardants in the indoor and outdoor dust of e-waste workshops: implication for on-site human exposure", Environ Sci Pollut Res, Vol. 22, pp. 5469-5480, 2015.

[12] J. K. Pradhan and S. Kumar, "Informal e-waste recycling: environmental risk assessment of heavy metal contamination in Mandoli industrial area, Delhi”, India Environ Sci Pollut Res, Vol. 21, pp. 7913-7928, 2014

[13] M. S. Sonmez and R. V. Kumar, "Leaching of waste battery paste components. Part 2: Leaching and desulphurisation of $\mathrm{PbSO}_{4}$ by citric acid and sodium citrate solution", Hydrometallurgy, Vol. 95, No. 1-2, pp. 82-86, 2009.

[14] M. G. Lionetto, C. Antonio and S. Trifone, "Earthworm Biomarkers as Tools for Soil Pollution Assessment", Soil Health and Land Use Management, pp. 305-332, 2012.

[15] K. Zheng, Z. Liu, Y. Li, Y. Cui and M. Li, "Toxicological responses of earthworm (Eisenia fetida) exposed to metal-contaminated soils", Environ Sci Pollut Res, Vol. 20, No. 12, pp. 8382-90, 2013 